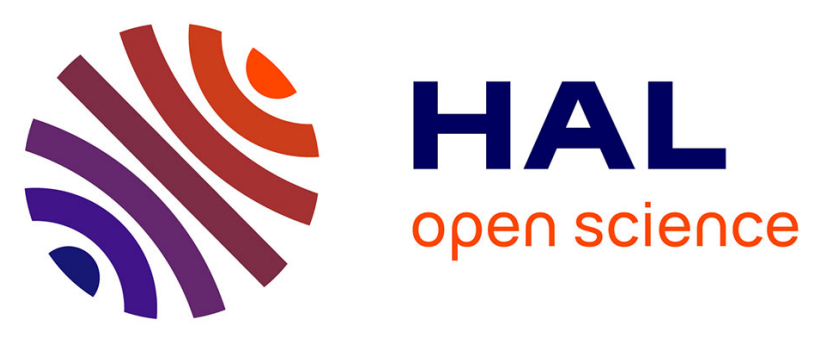

\title{
Transgenerational supplementation with eicosapentaenoic acid reduced the metabolic consequences on the whole body and skeletal muscle in mice receiving an obesogenic diet
}

Alexandre Pinel, Jean Paul Rigaudière, Chrystèle Jouve, Christophe

Montaurier, Céline Jousse, Marie Lhomme, Béatrice Morio, Frédéric Capel

\section{To cite this version:}

Alexandre Pinel, Jean Paul Rigaudière, Chrystèle Jouve, Christophe Montaurier, Céline Jousse, et al.. Transgenerational supplementation with eicosapentaenoic acid reduced the metabolic consequences on the whole body and skeletal muscle in mice receiving an obesogenic diet. European Journal of Nutrition, 2021, 10.1007/s00394-021-02502-6 . hal-03180100

\section{HAL Id: hal-03180100 \\ https://hal.inrae.fr/hal-03180100}

Submitted on 18 Nov 2021

HAL is a multi-disciplinary open access archive for the deposit and dissemination of scientific research documents, whether they are published or not. The documents may come from teaching and research institutions in France or abroad, or from public or private research centers.
L'archive ouverte pluridisciplinaire HAL, est destinée au dépôt et à la diffusion de documents scientifiques de niveau recherche, publiés ou non, émanant des établissements d'enseignement et de recherche français ou étrangers, des laboratoires publics ou privés. 


\title{
Transgenerational supplementation with eicosapentaenoic acid reduced the metabolic consequences on the whole body and skeletal muscle in mice receiving an obesogenic diet
}

\author{
Alexandre Pinel ${ }^{1} \cdot$ Jean Paul Rigaudière ${ }^{1} \cdot$ Chrystèle Jouve $^{1} \cdot$ Christophe Montaurier $^{1} \cdot$ Céline Jousse $^{1}$. \\ Marie LHomme L Béatrice Morio $^{3}$ (D) . Frédéric Capel ${ }^{1,4}$ (D)
}

Received: 1 September 2020 / Accepted: 22 January 2021

(c) Springer-Verlag GmbH, DE part of Springer Nature 2021

\begin{abstract}
Purpose The effect of manipulating the fatty acid profile of the diet over generations could affect the susceptibility to develop obesity and metabolic disorders. Although some acute effects were described, the impact of transgenerational continuous supplementation with omega 3 fatty acids on metabolic homeostasis and skeletal muscle metabolic flexibility during a nutritional stress is unknown.

Methods We analyzed the effect of an obesogenic diet in mice after transgenerational supplementation with an omega-3 rich oil (mainly EPA) or a control oil. Young F3 animals received a high fat and high sucrose diet for 4 months. Whole-body biometric data were recorded and lipidomic/transcriptomic adaptations were explored in the skeletal muscle.

Results F3 mice from the lineage supplemented with EPA gained less weight, fat mass, and exhibited better metabolic parameters after the obesogenic diet compared to mice from the control lineage. Transcriptomic exploration of skeletal muscle showed differential regulation of biological processes such as fibrosis, fatty acid catabolism, and inflammation between lineages. These adaptations were associated to subtle lipid remodeling of cellular membranes with an enrichment in phospholipids with omega 3 fatty acid in mice from the EPA lineage.

Conclusion Transgenerational and continuous intake of EPA could help to reduce cardiovascular and metabolic risks related to an unbalanced diet by the modulation of insulin sensitivity, fatty acid metabolism, and fibrosis in skeletal muscle.
\end{abstract}

Keywords Nutrition · Diet · Obesity $\cdot$ Lipid metabolism · Omega 3

$\begin{array}{ll}\text { Abbreviations } \\ \text { DPA } & \text { Docosapentaenoic acid } \\ \text { DHA } & \text { Docosahexaenoic acid } \\ \text { EE } & \text { Energy expenditure } \\ \text { EPA } & \text { Eicosapentaenoic acid }\end{array}$

Frédéric Capel

frederic.capel@inrae.fr

1 Unité de Nutrition Humaine (UNH), Institut national de recherche pour l'agriculture, l'alimentation et l'environnement (INRAE), Université Clermont Auvergne, CRNH Auvergne, 63000 Clermont-Ferrand, France

2 ICANalytics Lipidomic, Institute of Cardiometabolism and Nutrition (ICAN), Paris, France

3 CarMeN Laboratory, INSERM U1060, INRAE U1397, University Lyon 1, 69310 Pierre-Bénite, France

4 UFR de Medecine, UMR1019, Equipe ASMS, 28 Place Henri Dunant, BP 38, Clermont-Ferrand Cedex 1, 63001 Clermont-Ferrand, France

$\begin{array}{ll}\text { FA } & \text { Fatty acid } \\ \text { FDR } & \text { False discovery rate } \\ \text { HFD } & \text { High-fat diet } \\ \text { LFD } & \text { Low-fat diet } \\ \text { PL } & \text { Phospholipids } \\ \text { PLS-DA } & \text { Partial least squares discriminant analysis } \\ \text { PUFA } & \text { Polyunsaturated fatty acids } \\ \text { SFA } & \text { Saturated fatty acids } \\ \text { RQ } & \text { Respiratory quotient } \\ \text { TAG } & \text { Triacylglycerols }\end{array}$

\section{Introduction}

The prevalence of obesity has increased gradually across generations over the past $4-5$ decades. Predictions estimate that more than $35 \%$ of the world's population will be overweight and $20 \%$ will be obese by 2030 [1]. The risk for obesity differs between countries and sex or ethnic origin but 
represents a big socio-economic and public health problem [2]. Obesity is associated to a higher risk of disability and co-morbidities, such as cardiovascular diseases (CVD), type 2 diabetes, and cancer. Childhood obesity predisposes to the same disorders as adult obesity, but at a higher risk [3,4]. The development of obesity is a multifactorial but not inevitable process for a large majority of the population. If some genetic factors predispose to obesity, the accumulation of body fat is mainly related to the imbalance between energy intake and expenditure. Nutritional driven strategies must then be recommended. In this context, the specific contribution of dietary composition and nutrient content the different macronutrients in the development of obesity and the related metabolic abnormalities is still debated. The total amount of ingested fat has been frequently incriminated. However, the use of different analytical strategies and the now wellrecognized impact of the quality in food preferences may explain some discrepancies in the reports [5]. Hence, the dramatic qualitative evolution of fatty acid (FA) composition of dietary fats led to a large substitution of polyunsaturated FA (PUFAs) by saturated FA (SFAs). Furthermore among PUFAs, the current omega 6 (n-6) to omega $3(n-3)$ ratio in a typical Western diet is close to 15-20: 1 and contrasts with the recommended ratio of 2-4: 1 that has been established for the general population [6-8]. PUFAs are key structural components of cell membranes. They are incorporated into phospholipids and thereby modulate membrane fluidity and ligand-receptor interactions. PUFAs are also powerful signalling mediators and regulators of gene expression [9, 10], but n-3 FAs are known to be metabolized in molecules with healthier effects than $n-6$ FAs. Changing the $n-6$ to $n-3$ ratio in the diet could impact the development of obesity [11]. In addition, feeding mice with a Western-like diet exhibiting a n-6 to n-3 ratio higher than 25, gradually increased body fat mass over several generations [12]. The health effects of n-3 FAs have been extensively studied on different biological processes, but the mechanisms remain partially characterized. Protective effects against CVD, inflammatory diseases and insulin resistance were described [13-16]. These effects were probably partly related to biological adaptations in skeletal muscle which is a key regulator of glucose and more globally energy homeostasis. Major n-3 FA are eicosapentaenoic acid (EPA, C20:5 n-3), docosahexaenoic acid (DHA, C22:6 n-3), and alpha-linolenic acid (ALA, C18:3 n-3). EPA and DHA, but not their precursor ALA, were found to protect skeletal muscle from SFA-induced insulin resistance, through the enhancement of SFA oxidation and incorporation into non-toxic lipid fractions [17]. EPA and DHA could then increase skeletal muscle metabolic flexibility and lower SFA-induced lipotoxicity [18-20]. EPA, but not DHA, was found to protect mice from insulin resistance and accumulation of fat mass when given during a high fat and high sucrose challenge $[21,22]$. The long term, preventive effect remains unknown. Notably, the impact of transgenerational intake of long chain n-3 PUFAs on skeletal muscle has not been yet investigated. The aim of the present study was, therefore, to determine whether supplementation with fish oil containing a high proportion of n-3 FA, mainly in the form of EPA, to three generations of mice could be protective against fat accumulation, metabolic abnormalities and insulin resistance in skeletal muscle in response to a high fat high sucrose challenge.

\section{Materials and methods}

\section{Animals}

Three-month-old male and female $\mathrm{C} 57 \mathrm{bl} / 6 \mathrm{~J}$ mice were obtained from Janvier laboratories (Le Genest St Isle, France) and housed individually (males) or by two (females) during the 10 days of adaptation. These mice were considered as the F0 generation and received food (A03 diet from Safe diets, Augy, France) and water ad libitum. To obtain the F1 offspring, two females were mated with one male during 5 days. When gestation was validated by the appearance of a vaginal sperm plug, females were individually caged and randomly assigned to two dietary groups. The intervention group received the A03 diet supplemented with $1 \%$ (w:w) of fish oil (Polaris Omegavie 70 TG, EPA) containing $75 \%$ of $n-3$ FA, mainly in the form of EPA ( $75 \%$ of FA). The control group received the A03 diet supplemented with $1 \%$ of high oleic sunflower oil providing $83.5 \%$ of oleic acid (Lesieur, Coudekerque Branche, France). The fatty acid composition of the diets could be found in Supplementary Table 1. As illustrated on Supplementary Fig. S1, to generate F2 offspring in each dietary group, 16-week-old F1 males were mated with 16-weekold F1 females from the same dietary arm. To generate the F3 offspring generation in each dietary group, 16-week-old F2 males were mated with 16-week-old F2 females from the same dietary arm. The two diets that were assigned to $\mathrm{F} 0$ females at the beginning of gestation were used for all the offspring animals for mating, gestation, lactation and maintenance. Then all the F1, F2, and F3 offsprings followed the mother's diet and we finally obtained two groups of F3 animals, from a control/oleic or an EPA lineage. All the mice were maintained under a temperature-controlled environment and 12-12 h light-dark cycle at the animal facility of the INRA research center of Clermont-Ferrand/ Theix. All the procedures were followed to reduce the number and manipulation of the animals in the study. All protocols followed animal care guidelines of the European Union and were approved by the local research ethics committee (CEMEAA, 01276.01). 


\section{Obesogenic dietary intervention}

A obesogenic diet with a high content of fat and $20 \%$ of sucrose (HFD), without any supplementation with EPA or oleic oils, providing $45 \%$ of energy from fat (RD 12451 from Research diet, Brogaarden Gentofte, Denmark) was given to F2 and F3 males from the n-3 (HFepa) and control/oleic (HFoleic) lineages for 17 weeks. A third group of mice from the control/oleic lineage was maintained on a reference, low fat diet (LFD) providing 10\% of energy from fat (RD $12450 \mathrm{H}$ from Research diet) during the challenge as a reference group (Ref). The fatty acid composition of the diets could be found in Supplementary Table 1. Animal's weight was used as a grouping factor to constitute homogenous groups. No adverse effect was reported. At the end of the feeding period, the animals were sacrificed under anaesthesia with $4 \%$ isoflurane. Tissues were harvested, snap-frozen in liquid nitrogen and stored at $-80{ }^{\circ} \mathrm{C}$ until use.

\section{Biometric and calorimetric measurements}

Body composition was evaluated using EchoMRI ${ }^{\mathrm{TM}}$ (EchoMRI ${ }^{\circledR}$, Houston, TX). Dioxygen consumption $\left(\mathrm{VO}_{2}\right)$, carbon dioxide production $\left(\mathrm{VCO}_{2}\right)$, and activity of mice were measured during $24 \mathrm{~h}$ using a four-cage TSE System Pheno-Master/LabMaster (Bad Homburg, Germany). Energy expenditure was calculated using Weir's equation $\left(\mathrm{DE}(\mathrm{kJ})=\left(16,493 \times \mathrm{VO}_{2}\right)+\left(4629 \times \mathrm{VCO}_{2}\right)\right)[23]$. The respiratory quotient (RQ) was calculated as the ratio of $\mathrm{VCO}_{2}$ to $\mathrm{VO}_{2}$. Spontaneous activity was measured using a three dimensions meshing of light beams. Ambient temperature was maintained at $22{ }^{\circ} \mathrm{C}$, the light was on from 8 AM to $8 \mathrm{PM}$, and mice had free access to food and water. Data were collected after $24 \mathrm{~h}$ of acclimation, and the $\mathrm{O}_{2}$ and $\mathrm{CO}_{2}$ analysers were calibrated before each measurement period.

\section{Intraperitoneal insulin and glucose tolerance tests}

After $6 \mathrm{~h}$ of fasting, animals received an intraperitoneal injection of insulin $(1.2 \mathrm{mIU} / \mathrm{g}$, Novo rapid insulin, Novo nordisk, La défense, France) or glucose (2 mg/g, Sigma, France), and blood samples were collected from the tail vein $0,15,30,45,60$, and 120 min later. Blood glucose levels were determined using a commercial glucometer (One Touch $^{\circledR} \mathrm{Vita}^{\circledR}$, Issy les Moulineaux, France) for the calculation of the area under the curve.

\section{Lipidomic}

Whole pieces of gastrocnemius muscle were homogeneised in water using the Precellys system (Bertin Instruments, Montigny-le-Bretonneux, France). Volume equivalent to $0.2 \mathrm{mg}$ of tissue was supplemented with deuterium-labelled and odd-chain internal standards and lipids were extracted according to the modified Bligh and Dyer method. Briefly, tissue extracts were supplemented with $1.2 \mathrm{~mL}$ of a chloroform/methanol (1:2) and $0.25 \mathrm{~mL}$ of $\mathrm{HCl}(0.01 \mathrm{~N})$. The mixture was vortexed and supplemented with $0.4 \mathrm{~mL}$ of chloroform and $0.4 \mathrm{~mL}$ of water. The lower organic phase was dried and resuspended in LC/MS grade solvent. Analysis of phospholipids was performed as described previously [24]. Structural determination of major PL chains was performed by LC-MS/MS using reversed-phase separation on a Symmetry shield RP8 $50 \mathrm{~mm} \times 2.1 \mathrm{~mm}, 3.5 \mu \mathrm{m}$ column (Waters Corporation, Milford, MA, USA) as previously described [25] and negative ionization using precursor ion scans of FA chains. Triglycerides were analyzed simultaneously to phospholipids using the same extraction procedure and chromatographic method. TG were ionised in positive ion mode as ammonium adducts and detected as neutral loss of $\left[\mathrm{RCOO}+\mathrm{NH}_{3}\right]$ using scheduled MRM.

\section{Transcriptomic analysis}

Gene expression profiles were performed at the GeT-TRiX facility (GénoToul, Génopole Toulouse Midi-Pyrénées) using Agilent Sureprint G3 Mouse GE v2 microarrays $(8 \times 60 \mathrm{~K}$, design 074809$)$ following the manufacturer's instructions. For each sample, Cyanine-3 (Cy3) labelled cRNA was prepared from $200 \mathrm{ng}$ of total RNA using the One- Color Quick Amp Labeling kit (Agilent Technologies) according to the manufacturer's instructions, followed by Agencourt RNAClean XP (Agencourt Bioscience Corporation, Beverly, Massachusetts). Dye incorporation and cRNA yield were checked using Dropsense ${ }^{\mathrm{TM}} 96$ UV/VIS droplet reader (Trinean, Belgium). 600 ng of Cy3-labelled cRNA was hybridized on the microarray slides following the manufacturer's instructions. Immediately after washing, the slides were scanned on Agilent G2505C Microarray Scanner using Agilent Scan Control A.8.5.1 software and fluorescence signal extracted using Agilent Feature Extraction software v10.10.1.1 with default parameters. Microarray data and experimental details are available in NCBI's Gene Expression Omnibus [26] and are accessible through GEO Series accession number GSE141826 (https://www.ncbi.nlm.nih. gov/geo/query/acc.cgi?acc=GSE141826).

\section{RT-q PCR validation of gene expression change}

Total RNA were extracted from gastrocnemius muscle using TRIzol ${ }^{\circledR}$ reagent (Thermo Scientific) according to the manufacturer's instructions. Each total RNA sample was assessed for quantification and integrity using the Agilent Bioanalyzer (Agilent, Santa Clara, CA, USA). cDNAs were synthesized from $2 \mu \mathrm{g}$ of total RNA using the High Capacity cDNA Reverse Transcription Kit from Applied Biosystem 
(Thermo Scientific). The products of reverse transcription were used for Quantitative Real Time Polymerase Chain Reaction (qRT-PCR) using specific primers and Rotor-Gene SYBR Green PCR master mix on a Rotor-Gene Q system (Qiagen, Courtaboeuf, France). Messenger RNA (mRNA) quantification was assayed using the ddCT method using hprt as internal housekeeping gene. Primer sequences and PCR conditions are available upon request (frederic.capel@ inrae.fr).

\section{Statistics}

\section{Anthropometric, metabolic parameters}

As a primary outcome, means of body weight, fat and lean masses were compared using a Kruskal-Wallis test followed by a pairwise $t$ test adjusted for multiple comparison using the Benjamini and Hochberg correction. $p$ value lower than 0.05 were considered significant. Calorimetric data were explore using an ANCOVA. All analyses were performed using R [27] and Bioconductor packages (http:// www.bioconductor.org, v 3.6, [28]). Data are represented as mean \pm standard error of the mean (SEM).

\section{Microarray data}

Microarray data were analyzed using R. Raw data (median signal intensity) were filtered, $\log 2$ transformed and normalized using quantile method [29]. A model was fitted using the limma lmFit function [30]. Pair-wise comparisons between biological conditions were applied using specific contrasts and a correction for multiple testing using Benjamini-Hochberg procedure [31] to control the false discovery rate (FDR). Probes with FDR-adjusted $p<0.05$ were considered to be differentially expressed between conditions. Molecular signatures were explored using GeneTrail2 [32]. The lists of significantly regulated genes were used to identify enrichment of biological categories using an over-representation analysis. Only categories exhibiting a significant enrichment at $p<0.05$ using the Bonferroni correction or Benjamini-Yekutieli were considered. An exhaustive and integrative analysis was further performed using gene set enrichment analysis (GSEA) from GeneTrail2. In order to limit the effect of outliers, the unweighted version of GSEA implemented in Genetrail 2 evaluates whether the genes of the considered category are randomly distributed or accumulated on top or bottom of the list. To this aim, a Kolmogorov-Smirnov test was applied on fold change of genes with a differential expression between the Ref and the HF or HFepa groups or between the HF and HFepa groups at $p<0.05$ with no FDR adjustment. As recommended by the GeneTrail2 algorithm, only sets of genes identified at $p<0.05$ after adjustment for multiple testing using the Benjamini-Yekutieli method were considered.

\section{Lipidomic data}

Lipidomic data analysis was performed using multi experiment viewer (MeV) software version 4.9 (https://sourc eforge.net/projects/mev-tm4/) [33]. A one-way ANOVA was performed between the three groups, and a $t$ test was performed for two-group comparisons. Lipid features were considered significant for $p$ value lower than 0.05 . The Benjamini-Hochberg correction was used to control false discovery rate [31].

\section{Partial least squares discriminant analysis (PLS-DA)}

PLS-DA was done to classify samples using mixOmics package [34] under the R environment (https://CRAN.Rproject.org/package $=$ mixOmics $)$. The function perf of the mixOmics package was applied to evaluate a PLS-DA model, using fivefold cross-validation repeated ten times.

\section{Results}

\section{Transgenerational supplementation with EPA reduces the impact of the obesogenic diet in mice from $F 3$ generation}

A description of the biometric data obtained after the high fat challenge for F2 and F3 mice can be found in Supplementary Fig. S2. These observations showed a reduced accumulation of fat mass after the obesogenic diet in the HFepa group compared to the HFoleic group. Consequently, all further data were related to the animals from the F3 generation. One-month-old males from the F3 generation were $5 \%$ heavier $(p<0.05)$ in the EPA lineage compared to the oleic lineage, but the distribution of animal body weights did not seemed to differ between lineages in the three generations (Supplementary Fig. S3). This higher body weight was related to higher fat and lean masses (data not shown). No effect of the dietary lineage was observed on F3 females. Ten males matched for a body weight of 20-21 g from each dietary lineage (oleic and EPA) were challenged with a commercial obesogenic diet (HFoleic and HFepa) and compared to a reference group of ten body weight-matched reference mice from the control/oleic lineage, which was maintained on a normocaloric diet (Reference group). Mean body weight before the beginning of the challenge was similar between the three groups $(20.7 \pm 0.6,20.4 \pm 0.5,20.8 \pm 0.4$ in Ref, HFoleic and HFepa groups respectively, $p=\mathrm{NS}$ ). Food intake (in grams) from the three groups are presented in Supplementary Fig. S4. It was similar between groups 
when expressed in calories (data not shown). In these experimental conditions, mice from the HFepa group gained less weight and had a lower fat mass compared to the HFoleic group after the obesogenic challenge (Fig. 1).

\section{Transgenerational supplementation with EPA increased animal's energy expenditure}

Energy expenditure was evaluated 1-2 weeks before the end of the high-fat challenge. Mice from the EPA lineage exhibited a higher EE and a higher RQ compared to the two other groups (HFoleic and Ref). Interestingly, the higher EE was also observed in the F2 HFepa generation (Table 1). Exploration using ANCOVA of the relation between EE and lean mass evidenced that the higher EE in the HFepa group could be due to a higher lean mass (Fig. 2).

\section{Biological and molecular exploration in the third generation}

\section{Blood parameters}

Fasting plasma glucose and insulin were significantly lower in HFepa group compared to HFoleic group $(p<0.01$ and $p<0.05$, respectively, Table 1 ). In agreement with these measurement, the HOMA-IR index was significantly increased in the HFoleic group compared to reference and HFepa groups (Table 1). In contrast, plasma glycerol and non-esterified fatty acids (NEFA) were slightly higher in HFepa group compared to HFoleic group $(p=0.14$ and $p<0.05$, respectively).
Table 1 Metabolic characteristics of mice after the dietary intervention

\begin{tabular}{|c|c|c|c|}
\hline & Reference & HFoleic & HFepa \\
\hline $\begin{array}{l}\text { Glucose (mg/ } \\
\text { dL) }\end{array}$ & $194.8 \pm 11.6$ & $277.5 \pm 10.6^{* * *}$ & $217.1 \pm 17.5^{\dagger \dagger}$ \\
\hline $\begin{array}{l}\text { Insulin (pg/ } \\
\mathrm{mL})\end{array}$ & $68.0 \pm 7.3$ & $170.2 \pm 17.9 * * *$ & $104.9 \pm 21.4^{\dagger}$ \\
\hline $\begin{array}{l}\text { HOMA-IR } \\
\text { index }\end{array}$ & $0.91 \pm 0.14$ & $3.38 \pm 0.40 * * *$ & $1.73 \pm 0.38^{\dagger \dagger}$ \\
\hline TAG (g/L) & $0.313 \pm 0.012$ & $0.363 \pm 0.020$ & $0.395 \pm 0.029^{*}$ \\
\hline $\begin{array}{l}\text { Cholesterol } \\
(\mathrm{g} / \mathrm{L})\end{array}$ & $0.926 \pm 0.030$ & $1.111 \pm 0.040^{*}$ & $1.199 \pm 0.060 * * *$ \\
\hline Glycerol $(\mu \mathrm{m})$ & $209.8 \pm 11.1$ & $227.6 \pm 16.3$ & $264.9 \pm 16.9^{*}$ \\
\hline FFA (mm) & $0.359 \pm 0.036$ & $0.230 \pm 0.024$ & $0.400 \pm 0.058^{\dagger}$ \\
\hline $\mathrm{EE}(\mathrm{KJ} / 24 \mathrm{~h})$ & $39.98 \pm 0.61$ & $42.82 \pm 0.84 *$ & $44.25 \pm 0.99 * *$ \\
\hline $\begin{array}{l}\mathrm{EE}(\mathrm{KJ} / 24 \mathrm{~h} / \mathrm{g} \\
\mathrm{LM})\end{array}$ & $1.79 \pm 0.03$ & $1.80 \pm 0.03$ & $2.00 \pm 0.04 * *$ \\
\hline RQ & $0.92 \pm 0.02$ & $0.80 \pm 0.02 * * *$ & $0.85 \pm 0.01 *, \dagger$ \\
\hline $\begin{array}{l}\text { distance } \\
\qquad(\mathrm{m} / 24 \mathrm{~h})\end{array}$ & $427.58 \pm 68.44$ & $277.97 \pm 25.89$ & $316.03 \pm 32.20$ \\
\hline
\end{tabular}

Data are mean \pm SEM (plasma parameters, $n=10$ mice per group; $\mathrm{EE}, \mathrm{RQ}$ and distance, $n=8$ mice per group)

HOMA-IR homeostatic model assessment of insulin resistance, EE energy expenditure, $R Q$ respiratory quotient

${ }^{*} p<0.05$ vs Ref; $* * p<0.01$ vs Ref; *** $p<0.001$ vs Ref

${ }^{\dagger} p<0.05$ vs HFoleic; ${ }^{\dagger \dagger} p<0.01$ vs HFoleic

\section{Glucose tolerance test}

Administration of glucose induced an increase in blood glucose level in each group, but total area under the curve (AUC) was significantly increased only in the HFoleic group compared to the Ref group (Fig. 3b). AUC in the HFepa
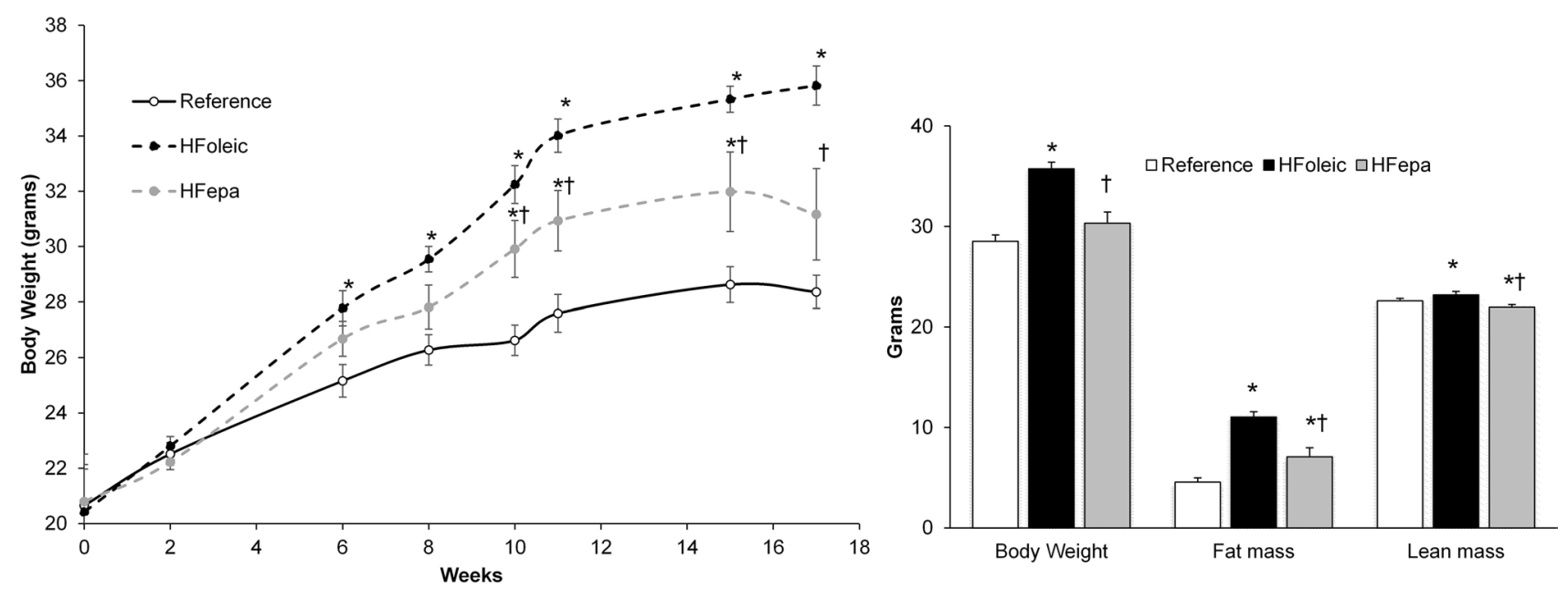

Fig. 1 Evolution of body weight during and body composition at the end of the high fat-diet challenge. Body weight is expressed in grams, fat and lean masses are expressed in percentage of body weight. Data are means \pm SEM for mice from the F3 generation only ( $n=10$ mice per group). *Means significantly different $(p<0.05)$ from reference group receiving a chow diet, ${ }^{\dagger}$ differs from HF oleic $(p<0.05)$ 


\section{Distribution of $\mathrm{RQ}$ \\ (Reference)}

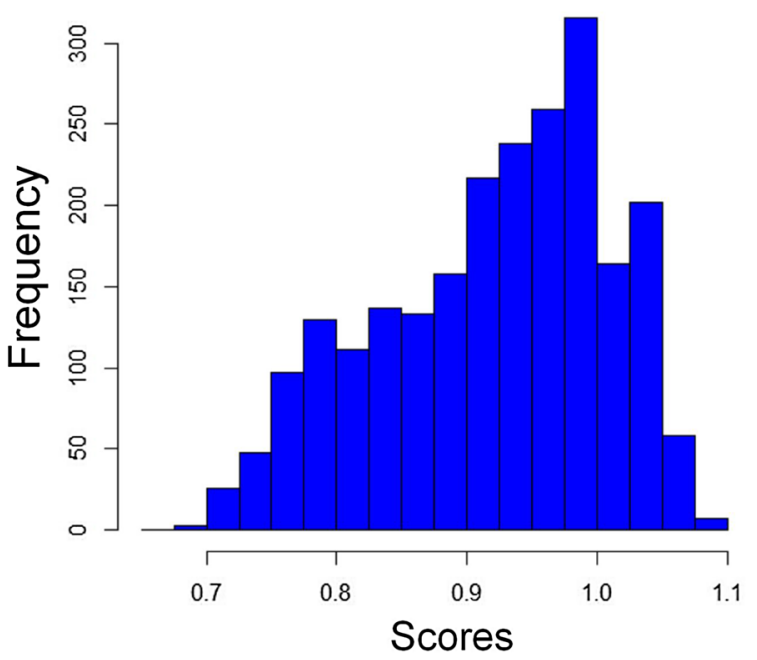

Distribution of $R Q$

(HFepa)

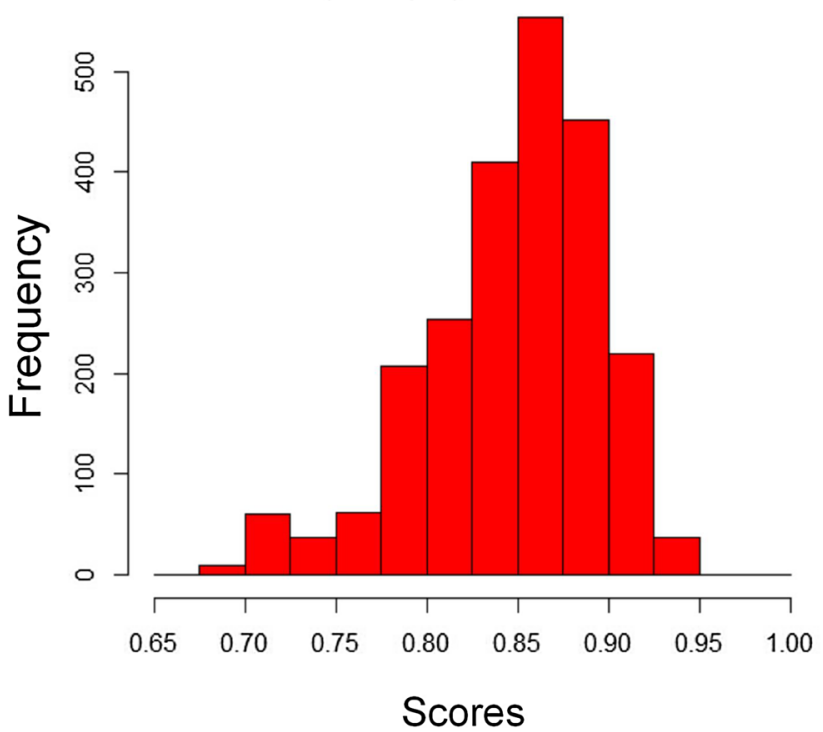

Distribution of $R Q$

(HFoleic)

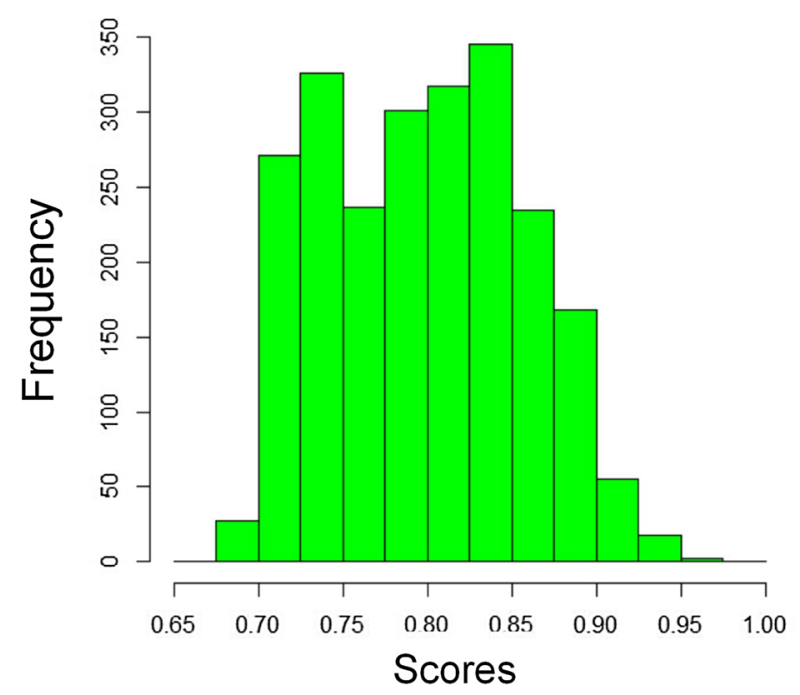

Regression of EE depending on lean mass

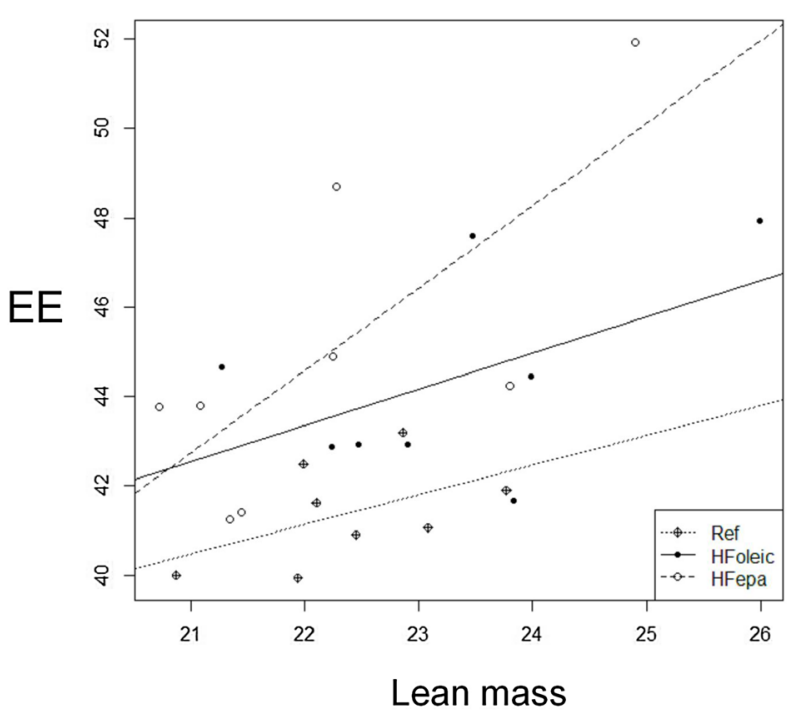

Fig. 2 Respiratory quotients (RQ) of the animals during the high fat-diet challenge. Distribution of RG is shown for each group (Reference, HFoleic and HFepa). A regression analysis of the association between RQ and lean mass (in grams) is also illustrated on the fourth panel

group did not differ from the Ref group. Sixty minutes after the injection, blood glucose exhibited a marked decreased in the HFepa group but was further increased in the HFoleic group.

\section{Insulin tolerance test}

The obesogenic diet-induced insulin resistance in the HFoleic $(p<0.05)$ and HFepa $(p=0.06)$ mice was compared to the Ref group. However, the area under the curve after 60 min was lower in HFepa group compared to HFoleic group but the difference did not reach the significance threshold $(131 \pm 21$ vs $162 \pm 24$ arbitrary units, respectively, $p=0.2$; Fig. 3a).

\section{Skeletal muscle gene expression}

As illustrated in Fig. 4a, pairwise comparison of microarray data between the three groups of mice revealed 829 probes differentially expressed between gastrocnemius 
a

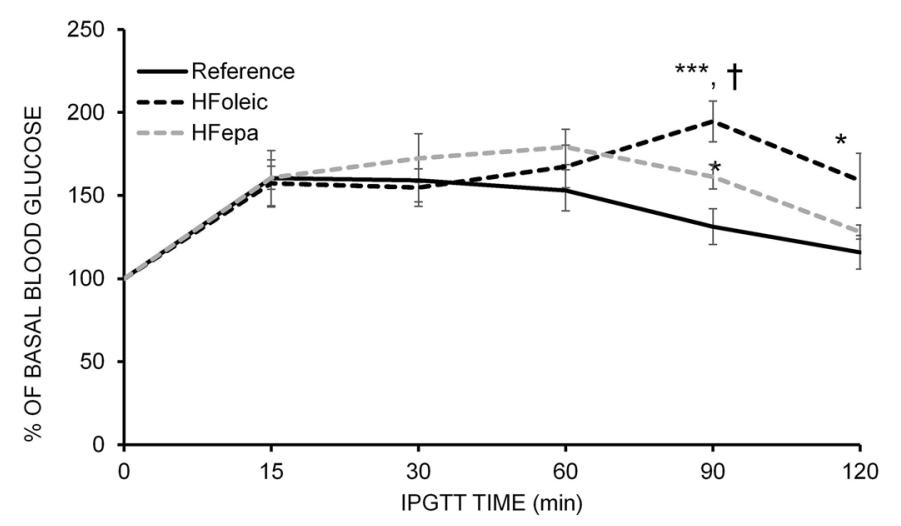

b

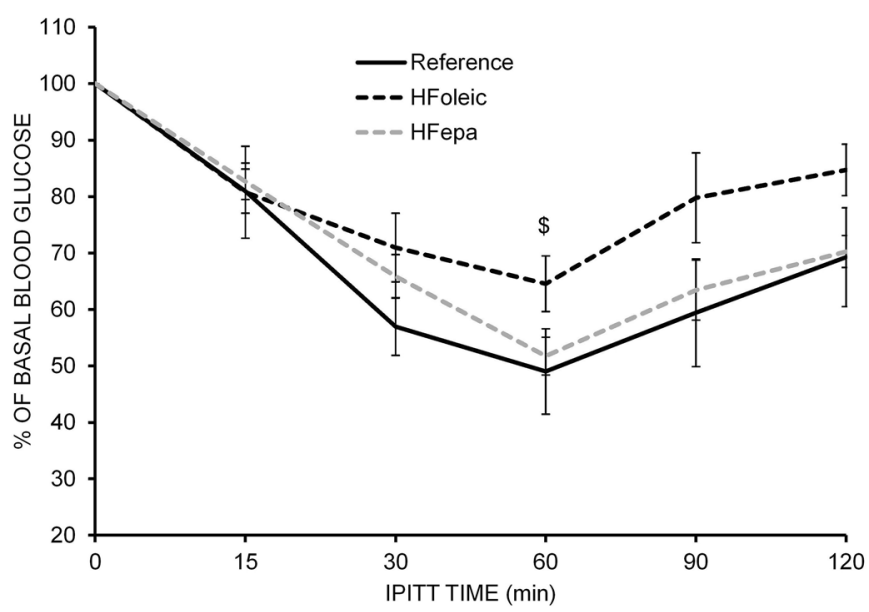

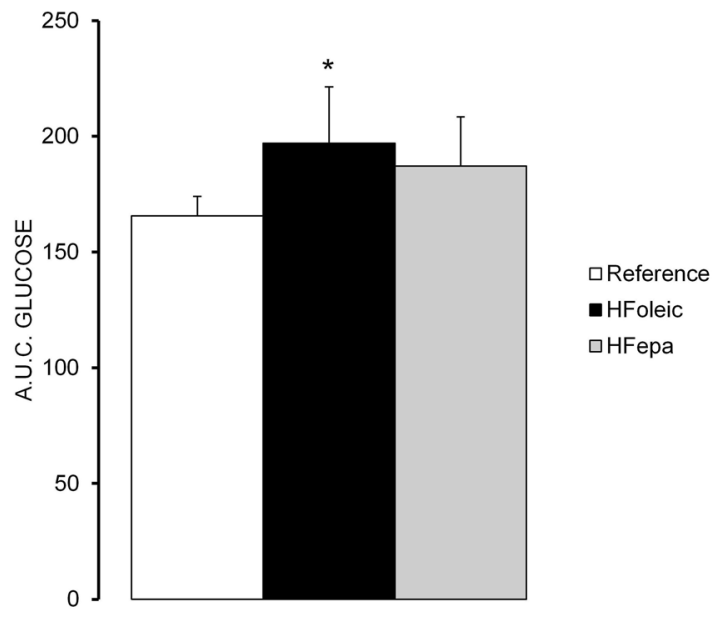

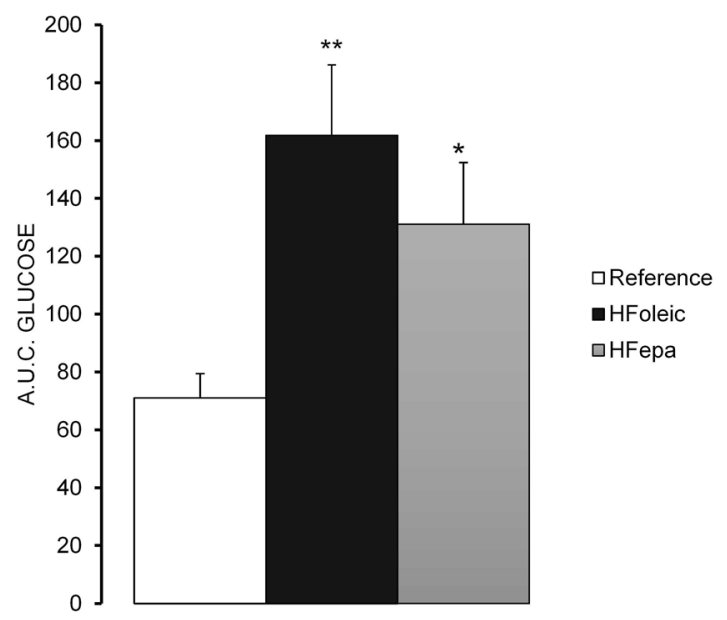

Fig. 3 Insulin and glucose tolerance tests. a Glucose tolerance was assessed by measuring blood glucose concentration following intraperitoneal glucose injection to fasted mice. Area under the glycaemic curve values was calculated from measured glucose in blood sampling during the test. b Insulin tolerance was assessed by measuring blood glucose concentration following intraperitoneal insulin injec-

muscles of Ref and HFoleic groups, 164 probes differentially expressed between the Ref and HFepa groups (all at FDRadjusted $p<0.05$ ). No differential expression was observed between HFoleic and HFepa groups using a FDR threshold of 0.05 . Only 93 of the 164 genes regulated in the HFepa group were also affected in the HFoleic group. Then, 71 genes were specifically regulated during the dietary challenge when comparing HFepa and Ref groups. The list of all significantly regulated genes is provided in supplementary materials. PLS-DA was used to detect similarities or dissimilarities between the three groups using all significantly regulated probes (900 unique probes identified at FDRadjusted $p<0.05$, whatever the comparison). Two dimensions explaining $65 \%$ of variance were enough to segregate tion to fasted mice. Area under the glycaemic curve values was calculated from measured glucose in blood sampling during the test. Data are means \pm SEM (arbitrary units, $n=9$ mice per group). Difference vs Reference group are illustrated as follow, $* p \leq 0.05 ; * * * p<0.001$, ${ }^{\$} p=0.1$

the groups (Fig. 4b). The PLS-DA plot illustrated in Fig. 4b shows that control, HFoleic and HFepa groups had distinct phenotypes. It confirmed that feeding mice with an obesogenic diet had a strong effect on skeletal muscle's gene expression whatever the lineage of the animals (control/oleic or EPA), but the cluster of the HFepa mice tended to move towards the cluster of the Ref group on the $X$-axis. Interestingly, the $Y$-axis mainly discriminates the EPA lineage from the control/oleic lineage with an error rate below $5 \%$.

Ontology analysis of differentially regulated genes showed that genes related to focal adhesion, angiogenesis, MAPK pathway, response to lipid were overexpressed by a HF challenge whatever the lineage of the animals. Significant enrichments in pathways related to inflammation, 

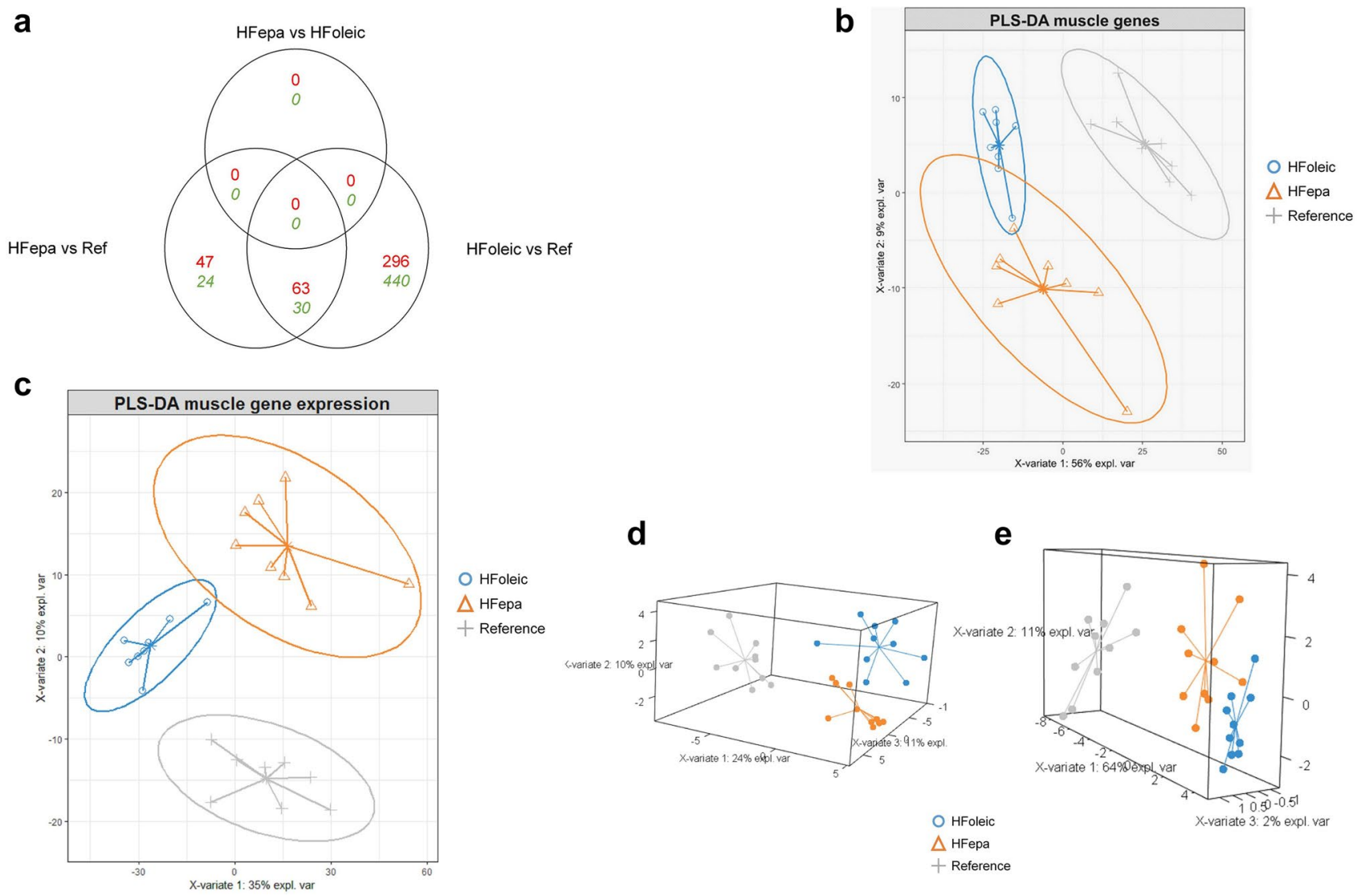

Fig. 4 Exploration of transcriptomic and lipidomic results. a Numbers of differentially expressed genes in the different comparisons (HFoleic vs Ref, HFepa vs Ref, HFepa vs HFoleic); numbers in red and green show up and down regulated genes respectively. b PLSDA plot of the 900 differentially regulated genes whatever the com-

apoptosis, oxidative stress, circadian regulation, proteolysis, FOXO signalling, Wnt signalling, lipid metabolism and cancer were observed when the HFoleic group was compared to the Ref group. Some transcription factors known to be involved in response to stressors, Sp1, Stat $1 / 3$, Atf 4 and Nrf2 were identified as potential mediators of these adaptations. As shown in Table 2, less processes or pathways were enriched in mice from the HFepa group compared to the Ref group. Significant enrichments in pathways related to fatty acid biosynthesis, glucose metabolism and the regulation of actin cytoskeleton were observed in the HFepa group compared to the Ref group. Variation suggested reduced FA synthesis from acetyl coA and stimulation of elongation leading to incorporation into non-toxic TAG. Among the list of the 71 genes that were specific to the comparison between Ref and HFepa groups (Fig. 4a), we identified processes related to lipid metabolism, cell development, MAPK pathways, and the regulation of gene expression or cytokine production (Supplementary Table 2). parison. c PLS-DA plot of the 1590 differentially regulated genes between HFepa and HFoleic groups, with no FDR correction. d, e PLS-DA plot of lipidomic data for phospholipids (d) and triacylglycerol (e) respectively

No differential gene expression was observed between the HFoleic and HFepa groups after FDR correction. Therefore, we considered the 1590 genes that had an accession number and exhibited a significant expression change at non adjusted $p<0.05$ between the HFepa and HFoleic groups, using the gene set enrichment analysis (GSEA) from the GeneTrail2 platform. GSEA allows the identification of similar expression patterns of genes that belong to the same biological category. To support this exploration, the variation in the mRNA level of some genes (Ucp3, Pdk4, Col1a1, Hif1a...) was validated by qPCR (Supplementary Table 3 ). PLS-DA using the 1590 genes clearly showed clustering of the samples within each group and the separation of the HFoleic group from the two others on the main axes that explained more than $35 \%$ of data variability (Fig. 4c). PLSDA classification error rate was estimated to be close to $0 \%$ (HFoleic) and 20\% (HFepa). The comparison of enriched gene sets from the differential analysis between the HFoleic and HFepa groups showed that the Wnt pathway, extracellular matrix-related events and collagen turnover processes 
Table 2 Significantly enriched biological pathways, processes and potential transcriptional regulators identified according to the transcriptomic experiment

\begin{tabular}{|c|c|c|}
\hline Name & Hits & $\begin{array}{l}\text { Adjusted } \\
p \text { value }\end{array}$ \\
\hline \multicolumn{3}{|l|}{ Wiki HFoleic } \\
\hline Focal adhesion-PI3K-Akt-mTOR-signaling pathway & 21 & $4.10 \mathrm{E}-009$ \\
\hline mRNA processing & 24 & $1.15 \mathrm{E}-008$ \\
\hline Diurnally regulated genes with circadian orthologs & 8 & $9.75 \mathrm{E}-006$ \\
\hline G1 to $\mathrm{S}$ cell cycle control & 8 & $3.71 \mathrm{E}-005$ \\
\hline IL-7 signaling pathway & 7 & $7.53 \mathrm{E}-005$ \\
\hline Focal adhesion & 11 & $3.86 \mathrm{E}-004$ \\
\hline Delta-notch signaling pathway & 8 & $4.24 \mathrm{E}-004$ \\
\hline Proteasome degradation & 7 & $5.34 \mathrm{E}-004$ \\
\hline MAPK signaling pathway & 10 & $6.40 \mathrm{E}-004$ \\
\hline Insulin signaling & 10 & $7.56 \mathrm{E}-004$ \\
\hline IL-6 signaling pathway & 8 & $1.10 \mathrm{E}-003$ \\
\hline Adipogenesis genes & 9 & $1.36 \mathrm{E}-003$ \\
\hline EGFR1 signaling pathway & 10 & $1.65 \mathrm{E}-003$ \\
\hline Amino acid metabolism & 7 & $4.65 \mathrm{E}-003$ \\
\hline Retinol metabolism & 5 & $5.22 \mathrm{E}-003$ \\
\hline DNA replication & 5 & $9.62 \mathrm{E}-003$ \\
\hline TNF-alpha NF-kB signaling pathway & 9 & $1.93 \mathrm{E}-002$ \\
\hline Chemokine signaling pathway & 9 & $2.16 \mathrm{E}-002$ \\
\hline Oxidative stress & 4 & $3.16 \mathrm{E}-002$ \\
\hline \multicolumn{3}{|l|}{ KEGG HFoleic } \\
\hline PI3K-Akt signalling pathway & 27 & $2.33 \mathrm{E}-013$ \\
\hline Pathways in cancer & 25 & $1.01 \mathrm{E}-012$ \\
\hline Focal adhesion & 14 & $7.66 \mathrm{E}-006$ \\
\hline Energy metabolism & 12 & $4.17 \mathrm{E}-005$ \\
\hline MAPK signalling pathway & 14 & $7.41 \mathrm{E}-005$ \\
\hline Viral carcinogenesis & 13 & $1.73 \mathrm{E}-004$ \\
\hline Cell cycle & 10 & $1.75 \mathrm{E}-004$ \\
\hline FoxO signaling pathway & 10 & $3.69 \mathrm{E}-004$ \\
\hline HIF-1 signaling pathway & 9 & $5.92 \mathrm{E}-004$ \\
\hline Endocytosis & 12 & $6.79 \mathrm{E}-004$ \\
\hline Spliceosome & 9 & $2.46 \mathrm{E}-003$ \\
\hline Prolactin signaling pathway & 7 & $2.61 \mathrm{E}-003$ \\
\hline Rap1 signaling pathway & 11 & $3.26 \mathrm{E}-003$ \\
\hline MicroRNAs in cancer & 12 & $5.34 \mathrm{E}-003$ \\
\hline Ras signaling pathway & 11 & $5.55 \mathrm{E}-003$ \\
\hline Hippo signaling pathway & 9 & $6.57 \mathrm{E}-003$ \\
\hline Amoebiasis & 8 & $8.37 \mathrm{E}-003$ \\
\hline Estrogen signaling pathway & 7 & $2.01 \mathrm{E}-002$ \\
\hline Peroxisome & 6 & $2.93 \mathrm{E}-002$ \\
\hline Mineral absorption & 5 & $3.10 \mathrm{E}-002$ \\
\hline Arginine and proline metabolism & 5 & $3.41 \mathrm{E}-002$ \\
\hline TNF signaling pathway & 7 & $3.58 \mathrm{E}-002$ \\
\hline Chemokine signaling pathway & 9 & $4.29 \mathrm{E}-002$ \\
\hline \multicolumn{3}{|l|}{ Biological processes HFoleic } \\
\hline Apoptotic signaling pathway (5) & 43 & $9.94 \mathrm{E}-021$ \\
\hline Cellular response to DNA damage stimulus (5) & 35 & $1.27 \mathrm{E}-012$ \\
\hline Response to lipid (5) & 35 & $2.14 \mathrm{E}-012$ \\
\hline
\end{tabular}


Table 2 (continued)

\begin{tabular}{|c|c|c|}
\hline Name & Hits & $\begin{array}{l}\text { Adjusted } \\
p \text { value }\end{array}$ \\
\hline Chromatin organization (5) & 35 & $2.10 \mathrm{E}-011$ \\
\hline Regulation of kinase activity (6) & 33 & $1.94 \mathrm{E}-010$ \\
\hline Regulation of cellular response to stress (4) & 29 & $2.76 \mathrm{E}-009$ \\
\hline Chemotaxis (4) & 27 & $3.02 \mathrm{E}-009$ \\
\hline Angiogenesis (4) & 25 & $4.56 \mathrm{E}-009$ \\
\hline Proteolysis involved in cellular protein catabolic process (6) & 24 & $2.93 \mathrm{E}-005$ \\
\hline Cytokine production (4) & 23 & $1.03 \mathrm{E}-004$ \\
\hline Autophagy (3) & 20 & $8.43 \mathrm{E}-005$ \\
\hline Inflammatory response (5) & 20 & $2.59 \mathrm{E}-003$ \\
\hline Wnt signaling pathway (6) & 19 & $3.34 \mathrm{E}-005$ \\
\hline Striated muscle tissue development (6) & 19 & $4.32 \mathrm{E}-005$ \\
\hline Phospholipid metabolic process (5) & 18 & $9.27 \mathrm{E}-006$ \\
\hline Muscle cell differentiation (5) & 18 & $1.61 \mathrm{E}-004$ \\
\hline Extracellular matrix organization (5) & 17 & $1.93 \mathrm{E}-007$ \\
\hline Fat cell differentiation (6) & 14 & $9.13 \mathrm{E}-005$ \\
\hline Response to endoplasmic reticulum stress (5) & 14 & $1.16 \mathrm{E}-004$ \\
\hline Circadian rhythm (3) & 10 & $3.62 \mathrm{E}-002$ \\
\hline Collagen biosynthetic process (5) & 6 & $2.21 \mathrm{E}-002$ \\
\hline \multicolumn{3}{|l|}{ Transcription factors HFoleic } \\
\hline Sp1 & 17 & $3.13 \mathrm{E}-008$ \\
\hline Stat3 & 7 & $1.70 \mathrm{E}-005$ \\
\hline Rela & 7 & $6.18 \mathrm{E}-005$ \\
\hline Stat1 & 5 & $3.89 \mathrm{E}-003$ \\
\hline Egr2 & 4 & $1.01 \mathrm{E}-002$ \\
\hline Nfil3 & 3 & $1.64 \mathrm{E}-002$ \\
\hline Atf4 & 4 & $1.87 \mathrm{E}-002$ \\
\hline Epas1 & 3 & $2.45 \mathrm{E}-002$ \\
\hline Cebpb & 6 & $2.46 \mathrm{E}-002$ \\
\hline Parp1 & 3 & $3.47 \mathrm{E}-002$ \\
\hline $\mathrm{Nfe} 212$ & 4 & $3.70 \mathrm{E}-002$ \\
\hline Name & Hits & $p$ value \\
\hline \multicolumn{3}{|l|}{ Wiki HFepa } \\
\hline Fatty acid biosynthesis & 4 & $3.03 \mathrm{E}-005$ \\
\hline Focal adhesion-PI3K-Akt-mTOR-signaling pathway & 7 & $5.32 \mathrm{E}-004$ \\
\hline Glycolysis and gluconeogenesis & 3 & $2.31 \mathrm{E}-002$ \\
\hline \multicolumn{3}{|l|}{ KEGG HFE } \\
\hline Focal adhesion & 5 & $1.37 \mathrm{E}-002$ \\
\hline PI3K-Akt signaling pathway & 6 & $1.72 \mathrm{E}-002$ \\
\hline Regulation of actin cytoskeleton & 5 & $1.76 \mathrm{E}-002$ \\
\hline MAPK signaling pathway & 5 & $3.37 \mathrm{E}-002$ \\
\hline \multicolumn{3}{|l|}{ Biological processes HFepa } \\
\hline Vasculature development (5) & 12 & $1.39 \mathrm{E}-005$ \\
\hline Response to lipid (5) & 12 & $1.79 \mathrm{E}-005$ \\
\hline Regulation of cell migration (5) & 12 & $2.68 \mathrm{E}-005$ \\
\hline Single organismal cell cell adhesion (4) & 12 & $4.22 \mathrm{E}-005$ \\
\hline Regulation of cell motility (4) & 12 & $4.51 \mathrm{E}-005$ \\
\hline Angiogenesis (4) & 11 & $2.43 \mathrm{E}-006$ \\
\hline Signal transduction by protein phosphorylation (4) & 11 & $3.76 \mathrm{E}-004$ \\
\hline
\end{tabular}


Table 2 (continued)

\begin{tabular}{lcc}
\hline Name & Hits & $p$ value \\
\hline MAPK cascade (5) & 10 & $3.00 \mathrm{E}-003$ \\
Response to growth factor (5) & 9 & $3.28 \mathrm{E}-003$ \\
Actin cytoskeleton organization (5) & 9 & $3.73 \mathrm{E}-003$ \\
Fat cell differentiation (6) & 6 & $1.32 \mathrm{E}-002$ \\
\hline
\end{tabular}

were up-regulated in the HFoleic group (Table 3). Specific overrepresentation of gene sets related to transcriptional regulation was also observed in the HFepa group. In the transcription factor-related collection of sets from GSEA, over-representation of targets of FOXO1, FOXO3, and $\mathrm{Nfe} 212$ were reported in the HFepa group compared to the HFoleic group (Table 3; Supplementary Table 4).

\section{Skeletal muscle lipidomic analysis}

The transcriptomic regulations related to the control of transcription, ligand-receptor interaction-induced signalling pathways (notably insulin signalling in the HFoleic group) and phospholipid/fatty acid metabolisms suggested the contribution of alterations in lipid homeostasis in skeletal muscle. We then explored the modulation of skeletal muscle sphingo-phospholipidome in response to the obesogenic challenge. No significant differences were observed in the total amount of each phospholipid (PL) classes (Supplementary Fig. S5) but 44 molecules were significantly affected by the transgenerational dietary intervention (Supplementary Table 5a). Approximately $70 \%$ of these PL were underrepresented in the gastrocnemius muscle from both HFoleic and HFepa groups compared to the Ref group. It concerned
Table 3 Enriched gene sets in the HFepa vs HFoleic comparison using gene set enrichment analysis

\begin{tabular}{|c|c|c|c|c|}
\hline \#Name & Reference & Hits & Adjusted $p$ val & $\begin{array}{l}\text { HFepa } \\
\text { vs } \\
\text { HFoleic }\end{array}$ \\
\hline Foxo1 & TRANSFAC & 4 & 0.029 & 1 \\
\hline Nicotinate and nicotinamide metabolism & KEGG & 2 & 0.031 & 0 \\
\hline Protein digestion and absorption & KEGG & 9 & 0.031 & 0 \\
\hline Spliceosome & KEGG & 17 & 0.052 & 1 \\
\hline Cholinergic synapse & KEGG & 10 & 0.061 & 0 \\
\hline ECM-receptor interaction & KEGG & 11 & 0.061 & 0 \\
\hline Epstein-Barr virus infection & KEGG & 20 & 0.076 & 1 \\
\hline Wnt signaling pathway & KEGG & 13 & 0.076 & 0 \\
\hline mRNA processing & Wiki pathways & 58 & $4 e-4$ & 1 \\
\hline Id signaling pathway & Wiki pathways & 10 & 0.032 & 1 \\
\hline Wnt signaling pathway NetPath & Wiki pathways & 9 & 0.097 & 0 \\
\hline RNA_processing & GO biological process & 81 & 0.013 & 1 \\
\hline Response_to_lipid & GO biological process & 49 & 0.013 & 1 \\
\hline Cartilage_development & GO biological process & 18 & 0.081 & 0 \\
\hline mRNA_metabolic_process $(6)$ & GO biological process & 62 & 0.099 & 1 \\
\hline Collagen biosynthesis and modifying enzymes & Reactome & 8 & $4 e-4$ & 0 \\
\hline Collagen degradation & Reactome & 7 & 0.001 & 0 \\
\hline mRNA splicing—major pathway & Reactome & 21 & 0.030 & 1 \\
\hline ECM proteoglycans & Reactome & 5 & 0.040 & 0 \\
\hline Signaling by PDGF & Reactome & 5 & 0.079 & 0 \\
\hline Glycosaminoglycan_binding & GO molecular function & 16 & 0.013 & 0 \\
\hline Heparin_binding & GO molecular function & 14 & 0.013 & 0 \\
\hline Fibronectin_binding & GO molecular function & 4 & 0.068 & 0 \\
\hline Ion_channel_activity & GO molecular function & 19 & 0.096 & 0 \\
\hline Substrate-specific_channel_activity & GO molecular function & 19 & 0.096 & 0 \\
\hline
\end{tabular}

$p$ val $p$ value 
mostly phosphatidyl ethanolamine (PE), phosphatidyl glycerol (PG), phosphatidic acid (PA), and phosphatidyl inositol (PI) species. Pairwise comparison between the HFoleic and HFepa groups suggested differential relative amount of four ceramides, one sphingomyelin and five phospholipids ( $p<0.05$, no FDR correction). The amounts of the four ceramides were reduced in skeletal muscle from the HFepa group compared to the HFoleic group. The global amount of ceramides did not significantly differ between groups but tended to be higher in HFoleic and HFepa groups compared to the Ref group ( 0.0114 and 0.0112 vs $0.0099 \mathrm{nmol} / \mathrm{mg}$ tissue, respectively, $p \leq 0.1$ vs Ref for each comparison). The amounts of PI (38:6) and PC (40:8), two PL which contain the $n-3$ fatty acid DHA, were increased in the HFepa group compared to the HFoleic group. Interestingly, PLS-DA of all phospholipid and sphingolipid data was able to discriminate the HFepa and HFoleic groups despite a stronger impact of the HF diet on the global variance (Fig. 4d). Prediction accuracy was estimated to be high for Ref group (100\%) and close to $75 \%$ for HFepa and HFoleic groups (data not shown).

Lipidomic analysis in the gastrocnemius muscle also revealed that the content of 38 triglycerides (TAG) was significantly affected by the obesogenic challenge (Supplementary Table 5b). When the HFoleic and HFepa groups were compared to the Ref group of mice, 41 or 34 TAG exhibited a differential amount, respectively, and the relative proportions of over- or under-represented TAG were very similar. No difference could be observed between the HFoleic and HFepa groups after FDR correction of the $p$ values, but 10 TAG tended to be differentially represented. Two TAG which contain DPA at the sn1 position tended to be overrepresented in the muscles from the HFepa group compared to the HFoleic group. On the contrary, TAG containing oleic (18:1) or palmitic (16:0) fatty acids at the sn1 position tended to be depleted in the HFepa group compared to the HFoleic group. The PLSDA plot of the relative molecular percentage of the significant molecules in each group confirmed that despite a good prediction accuracy $(71 \%$, $78 \%$, and $100 \%$ for HFepa, HFoleic and Ref groups, respectively), few differences could be detected between HFepa and HFoleic groups. However minor differences allowed a slight separation of HFepa and HFoleic plots (Fig. 4e).

\section{Discussion}

The early-life nutrition can markedly influence individual susceptibility to develop metabolic disorders and obesity when exposed to nutritional stressors through different mechanisms. Among them, the regulation of gene expression and epigenetic modifications are probably involved in the genesis of an adaptive response [35]. The continuous exposure to a high n-6 to n-3 ratio from foetal to adult age over generations promoted inflammation and fat mass accretion in mice [12]. Then, the non-genetic inheritance across generations includes the contribution of parent's diet, suggesting that early prevention of metabolic and cardiovascular risk induced by a nutritional stress is possible.

In the present study, we tried to determine if the supplementation of mice with n-3 FA over three generations could affect the metabolic susceptibility to an obesogenic diet. Both male and female C57B16J mice breeders were fed a chow diet enriched with $1 \%$ of fish oil, high in $n-3$ FA mainly in the form of EPA, and compared to a group receiving $1 \%$ of high oleic sunflower oil as control. Diets were given to pregnant F0 females and maintained for F1, F2, and F3 generations throughout their life. When young F3 males from the EPA and oleic/control lineages were fed with a HFD after weaning, a significant lower increase in fat mass and metabolic abnormalities was observed in animals from the EPA lineage. Glucose homeostasis was also less affected and energy expenditure was higher in animals from the EPA lineage compared to the oleic/control lineage. In agreement with this, EPA was previously found to prevent the excessive accumulation of fat mass and the development of metabolic abnormalities in mice fed a HFD [21]. Given that these effects were observed in male mice, it could be relevant to reproduce the experiment in female animals to expand the relevance of our results. Considering the major role of skeletal muscle in energy homeostasis and FA oxidation, these observations led us to search for biological and molecular determinants of these differences.

Our observations were consistent with the notion that transgenerational and continuous intake of n-3 FA could reduce cardiovascular and metabolic risks related to an unbalanced diet. The PLS-DA explorations of transcriptomic and lipidomic data clearly showed differences in the molecular and structural adaptations. Even if the magnitude of the effect was moderate, some biological processes or cellular pathways exhibited a specific signature of the transgenerational dietary supplementation. A major difference was related to the regulation of extracellular matrix (ECM). Accumulation of ECM in a tissue is a hallmark of fibrosis and collagen type I. It is a major component of fibrotic ECM [36]. A common mesenchymal progenitor was shown to induce intermuscular fat accumulation and fibrosis in skeletal muscle under pathological conditions [37, 38]. Transforming growth factor-beta (TGF-b) was identified as an inducer of fibrosis and fiber atrophy in skeletal muscle $[39,40]$. Increased expression of several collagen isoforms and some inhibitors of matrix metalloproteinases in animals from the control lineage receiving a HFD suggested replacement of muscle fibres by fibrotic tissue. The wnt signalling has been proposed to control skeletal muscle fibrosis through mechanisms which are still partially understood 
[41]. Supporting this hypothesis, this signalling pathway exhibited a differential transcriptomic signature between the two lineages and should then explain the lower activation of fibrotic markers in the EPA lineage compared to the control/ oleic lineage. Cellular stress, inflammation, and fibrosis are closely related [42]. It has been recently proposed that glycolysis and fatty acid catabolism could have opposite effects on fibrosis development [43]. In agreement with this observation, we observed a preferential decrease in genes involved in glycolysis and increase in genes related to fatty oxidation in animals from the EPA lineage. The increased potential for FA oxidation after an obesogenic challenge in the EPA lineage may be mediated by modifications in mitochondria oxidative capacities. When GSEA was performed on the different comparisons, FA oxidation was an enriched pathway in skeletal muscle from mice fed with the obesogenic diet whatever the lineage. However, more genes from this categories were overrepresented and overexpressed (Cpt2, Hadha, Hadhb...) in the EPA lineage (Supplementary Table 6). The differential expression in Pdk4 mRNA between HFepa and HFoleic groups further support this notion. Pdk4 is an inhibitor of pyruvate carboxylase, contributing to a preferential oxidation of fatty acids [44]. Overexpression of three thioesterases were observed in mice fed a HFD from the EPA lineage compared to the control/oleic lineage. These enzymes are crucial regulators of intracellular $\mathrm{CoASH}$ homeostasis and could regulate mitochondria activity in a UCP3-dependent manner [45, 46]. Interestingly, Ucp3 gene expression was increased after transgenerational intake of EPA. This observation also supported the concept that oxidative stress could be alleviated under nutritional stress after supplementation with omega 3 FA over generations. In agreement with this hypothesis, the mRNA levels of Foxo1, Foxo3, and Nfe2l2 (Nrf2) target-genes were significantly lower in the HFoleic group, but not in the HFepa group compared to the Ref group. The enrichment in SP1 and Stat3 targets in the list of genes affected by the obesogenic diet in the HFoleic group further support our conclusions. The significant downregulation of Foxo1 expression in the HFoleic group may have induced the decrease in Pdk4 mRNA level in mice from this group [47]. It was shown that muscle specific downregulation of FOXO protein expression reduced insulin sensitivity and mitochondria abundance within the tissue [48]. Altogether, these observations suggested that FOXO transcription factor family may be a central point of the differential adaptations between lineages in the skeletal muscle in response to an obesogenic diet. The epigenetic mechanisms that could regulate FOXO protein activities remain to be identified. However, even if some controversies exist today, such a hypothesis seems conceivable [49].

Only few differences were identified between the two lineages on skeletal muscle lipidomic signature, but it confirmed the association between the lipidomic signature and metabolic adaptations. Two phospholipids (PC 40:8 and PI 38:6) containing DHA tended to be enriched in skeletal muscle from HFepa compared to HFoleic mice. The PC molecule was previously found to be significantly enriched in skeletal muscle from mice with peroxisome proliferatoractivated receptor gamma coactivator 1-alpha overexpression [50]. Few ceramide species tended to be reduced in the EPA lineage compared to the control lineage but total ceramide content tended to be increased in both lineages compared to the reference group of mice fed with the LF/ reference diet. This is of particular interest since these molecules are known mediator of insulin resistance, confirming the beneficial effect of omega $3 \mathrm{FA}$ on lipotoxicity. Analysis of TAG composition further support this notion. Enrichment in DPA was observed in TAG from mice that received transgenerational supplementation with EPA. DPA can accumulate after EPA supplementation because the rate limiting step is the bioconversion of DPA to DHA. These results suggest as possible role of the identified molecules in cellular adaptations to nutritional stressors. Our data about the reduced impact of the obesogenic diet on skeletal muscle homeostasis in mice receiving a transgenerational supplementation with EPA provide new information in this area of research and support the notion that a regular intake of omega $3 \mathrm{FA}$ is beneficial for human's health. However our observations were obtained in an animal model, for which the study of a transgenerational effect of a nutritional intervention is easier to be done. Validation in other strains or animal species should be obtained to further support our results. A human clinical study would not be applicable to translate this work and the comparison of populations with known low or high intake of omega 3 FA is difficult. We also acknowledge that few differences were observed between the three lineages after the obesogenic challenge. However, we validated the transcriptomic using RT-qPCR and used GeneTrail to compare our two HFD groups because it implements a statistical test with FDR correction. Despite this, our bioinformatic exploration of the data would miss an investigation at the protein level. In conclusion, the present study showed that transgenerational supplementation with n-3 FA sources, especially enriched in EPA, could have beneficial health effects and counter individual susceptibility to metabolic stressors. The supplementation could mediate molecular adaptations in insulin sensitive tissues, leading to an improvement in metabolic flexibility linked to glucosefatty acid utilization and to limitation of fibrotic processes.

Supplementary Information The online version contains supplementary material available at https://doi.org/10.1007/s00394-021-02502-6.

Acknowledgements We are grateful to the staff of the Installation Expérimentale de Nutrition (INRAE of Saint Genès ChampanelleTheix) for providing everyday care to the animals; Elodie Pitois, and Sarah De Saint Vincent for their expert technical assistance to the 
study. We thank Claire Naylies and Yannick Lippi for their contribution to microarray fingerprints acquisition and microarray data analysis carried out at GeT-TRiX Genopole Toulouse Midi-Pyrénées facility (Toxalim (Research Centre in Food Toxicology), Université de Toulouse, INRA, ENVT, INP-Purpan, UPS, Toulouse, France).

Author contributions $\mathrm{AP}, \mathrm{CeJ}, \mathrm{BM}$ and $\mathrm{FC}$ contributed to the conception and design of the study. JPR, ChJ, CM, MLH, FC performed the experiments. Data were analyzed by JPR, CM, MLH and FC. The article was written by FC and critically revised by AP and BM.

Funding Authors were supported by Avril in partnership with Lesieur.

Data availability Transcriptomic raw data are accessible through GEO Series accession number GSE141826 (https://www.ncbi.nlm.nih.gov/ geo/query/acc.cgi?acc $=$ GSE141826). All other request should be addressed to the corresponding author.

\section{Compliance with ethical standards}

Conflict of interest The authors have no financial support or other financial interests which could represent a conflict of interest with regard to the work.

Consent for publication All authors approved the final version of the manuscript.

\section{References}

1. Kelly T, Yang W, Chen CS, Reynolds K, He J (2008) Global burden of obesity in 2005 and projections to 2030. Int J Obes 32(9):1431-1437. https://doi.org/10.1038/ijo.2008.102

2. Hruby A, Hu FB (2015) The epidemiology of obesity: a big picture. PharmacoEconomics 33(7):673-689. https://doi. org/10.1007/s40273-014-0243-x

3. Freedman DS, Khan LK, Dietz WH, Srinivasan SR, Berenson GS (2001) Relationship of childhood obesity to coronary heart disease risk factors in adulthood: the Bogalusa Heart Study. Pediatrics 108(3):712-718

4. Bjerregaard LG, Adelborg K, Baker JL (2019) Change in body mass index from childhood onwards and risk of adult cardiovascular disease. Trends Cardiovasc Med. https://doi.org/10.1016/j. tcm.2019.01.011

5. Riccardi G, Giacco R, Rivellese AA (2004) Dietary fat, insulin sensitivity and the metabolic syndrome. Clin Nutr 23(4):447-456. https://doi.org/10.1016/j.clnu.2004.02.006

6. Simopoulos AP (2010) The omega-6/omega-3 fatty acid ratio: health implications. OCL 17(5):267-275

7. Simopoulos AP, Leaf A, Salem N Jr (2000) Workshop statement on the essentiality of and recommended dietary intakes for Omega-6 and Omega-3 fatty acids. Prostaglandins Leukot Essent Fatty Acids 63(3):119-121. https://doi.org/10.1054/ plef.2000.0176

8. ANSES, rapport d'expertise collective (2011). Actualisation des apports nutritionnels conseillés pour les acides gras. https://www. anses.fr/fr/content/actualisation-des-apports-nutritionnels-conse ill\%C3\%A9s-pour-les-acides-gras-version-int\%C3\%A9grant-0. Accessed 01 Sept 2020

9. Spite M, Claria J, Serhan CN (2014) Resolvins, specialized proresolving lipid mediators, and their potential roles in metabolic diseases. Cell Metab 19(1):21-36. https://doi.org/10.1016/j. cmet.2013.10.006

10. Masoodi M, Kuda O, Rossmeisl M, Flachs P, Kopecky J (2015) Lipid signaling in adipose tissue: connecting inflammation \& metabolism. Biochim Biophys Acta 4:503-518. https://doi. org/10.1016/j.bbalip.2014.09.023

11. Ailhaud G, Massiera F, Weill P, Legrand P, Alessandri JM, Guesnet P (2006) Temporal changes in dietary fats: role of $n-6$ polyunsaturated fatty acids in excessive adipose tissue development and relationship to obesity. Prog Lipid Res 45(3):203-236. https://doi.org/10.1016/j.plipres.2006.01.003

12. Massiera F, Barbry P, Guesnet P, Joly A, Luquet S, MoreilhonBrest C, Mohsen-Kanson T, Amri EZ, Ailhaud G (2010) A Western-like fat diet is sufficient to induce a gradual enhancement in fat mass over generations. J Lipid Res 51(8):2352-2361. https:// doi.org/10.1194/jlr.M006866

13. Lorente-Cebrian S, Costa AG, Navas-Carretero S, Zabala M, Martinez JA, Moreno-Aliaga MJ (2013) Role of omega-3 fatty acids in obesity, metabolic syndrome, and cardiovascular diseases: a review of the evidence. J Physiol Biochem 69(3):633-651. https ://doi.org/10.1007/s13105-013-0265-4

14. Pinel A, Morio-Liondore B, Capel F (2014) n-3 Polyunsaturated fatty acids modulate metabolism of insulin-sensitive tissues: implication for the prevention of type 2 diabetes. J Physiol Biochem 70(2):647-658. https://doi.org/10.1007/s13105-013-0303-2

15. Calder PC (2010) Omega-3 fatty acids and inflammatory processes. Nutrients 2(3):355-374. https://doi.org/10.3390/nu203 0355

16. Storlien LH, Kraegen EW, Chisholm DJ, Ford GL, Bruce DG, Pascoe WS (1987) Fish oil prevents insulin resistance induced by high-fat feeding in rats. Science 237(4817):885-888

17. Pinel A, Rigaudiere JP, Laillet B, Pouyet C, Malpuech-Brugere C, Prip-Buus C, Morio B, Capel F (2015) N-3 PUFA differentially modulate palmitate-induced lipotoxicity through alterations of its metabolism in C2C12 muscle cells. Biochim Biophys Acta 1:12-20. https://doi.org/10.1016/j.bbalip.2015.10.003

18. Kelley DE, Mandarino LJ (2000) Fuel selection in human skeletal muscle in insulin resistance: a reexamination. Diabetes 49(5):677-683

19. Hessvik NP, Bakke SS, Fredriksson K, Boekschoten MV, Fjorkenstad A, Koster G, Hesselink MK, Kersten S, Kase ET, Rustan AC, Thoresen GH (2010) Metabolic switching of human myotubes is improved by n-3 fatty acids. J Lipid Res 51(8):2090-2104

20. Capel F, Acquaviva C, Pitois E, Laillet B, Rigaudiere JP, Jouve C, Pouyet C, Gladine C, Comte B, Vianey Saban C, Morio B (2015) DHA at nutritional doses restores insulin sensitivity in skeletal muscle by preventing lipotoxicity and inflammation. J Nutr Biochem 26(9):949-959. https://doi.org/10.1016/j.jnutb io.2015.04.003

21. Pinel A, Pitois E, Rigaudiere JP, Jouve C, De Saint-Vincent S, Laillet B, Montaurier C, Huertas A, Morio B, Capel F (2016) EPA prevents fat mass expansion and metabolic disturbances in mice fed with a Western diet. J Lipid Res 57(8):1382-1397. https://doi. org/10.1194/jlr.M065458

22. Kalupahana NS, Claycombe K, Newman SJ, Stewart T, Siriwardhana N, Matthan N, Lichtenstein AH, Moustaid-Moussa N (2010) Eicosapentaenoic acid prevents and reverses insulin resistance in high-fat diet-induced obese mice via modulation of adipose tissue inflammation. J Nutr 140(11):1915-1922. https://doi.org/10.3945/ jn. 110.125732

23. Weir JB (1990) New methods for calculating metabolic rate with special reference to protein metabolism. Nutrition 6(3):213-221

24. Giraud C, Tournadre A, Pereira B, Dutheil F, Soubrier M, Lhomme M, Kontush A, Sebedio JL, Capel F (2019) Alterations of HDL particle phospholipid composition and role 
of inflammation in rheumatoid arthritis. J Physiol Biochem 75(4):453-462. https://doi.org/10.1007/s13105-019-00694-4

25. Camont L, Lhomme M, Rached F, Le Goff W, Negre-Salvayre A, Salvayre R, Calzada C, Lagarde M, Chapman MJ, Kontush A (2013) Small, dense high-density lipoprotein-3 particles are enriched in negatively charged phospholipids: relevance to cellular cholesterol efflux, antioxidative, antithrombotic, anti-inflammatory, and antiapoptotic functionalities. Arterioscler Thromb Vasc Biol 33(12):2715-2723. https://doi.org/10.1161/ATVBA HA. 113.301468

26. Edgar R, Domrachev M, Lash AE (2002) Gene expression omnibus: NCBI gene expression and hybridization array data repository. Nucleic Acids Res 30(1):207-210. https://doi.org/10.1093/ nar/30.1.207

27. Team RDC (2009) R: a language and environment for statistical computing. R Foundation for Statistical Computing, Vienna, Austria. ISBN 3-900051-07-0. http://www.R-project.org. Accessed 01 Sept 2018

28. Gentleman RC, Carey VJ, Bates DM, Bolstad B, Dettling M, Dudoit S, Ellis B, Gautier L, Ge Y, Gentry J, Hornik K, Hothorn T, Huber W, Iacus S, Irizarry R, Leisch F, Li C, Maechler M, Rossini AJ, Sawitzki G, Smith C, Smyth G, Tierney L, Yang JY, Zhang J (2004) Bioconductor: open software development for computational biology and bioinformatics. Genome Biol 5(10):R80. https://doi.org/10.1186/gb-2004-5-10-r80

29. Bolstad BM, Irizarry RA, Astrand M, Speed TP (2003) A comparison of normalization methods for high density oligonucleotide array data based on variance and bias. Bioinformatics 19(2):185193. https://doi.org/10.1093/bioinformatics/19.2.185

30. Smyth GK (2004) Linear models and empirical bayes methods for assessing differential expression in microarray experiments. Stat Appl Genet Mol Biol. https://doi.org/10.2202/1544-6115.1027

31. Benjamini Y, Hochberg Y (1995) Controlling the false discovery rate: a practical and powerful approach to multiple testing. J R Stat Soc Ser B Methodol 57(1):289-300

32. Stockel D, Kehl T, Trampert P, Schneider L, Backes C, Ludwig N, Gerasch A, Kaufmann M, Gessler M, Graf N, Meese E, Keller A, Lenhof HP (2016) Multi-omics enrichment analysis using the GeneTrail2 web service. Bioinformatics 32(10):1502-1508. https ://doi.org/10.1093/bioinformatics/btv770

33. Saeed AI, Sharov V, White J, Li J, Liang W, Bhagabati N, Braisted J, Klapa M, Currier T, Thiagarajan M, Sturn A, Snuffin M, Rezantsev A, Popov D, Ryltsov A, Kostukovich E, Borisovsky I, Liu Z, Vinsavich A, Trush V, Quackenbush J (2003) TM4: a free, open-source system for microarray data management and analysis. Biotechniques 34(2):374-378. https://doi.org/10.2144/03342mt01

34. Le Cao KH, Rohart F, Gonzalez I, Dejean S, Gautier B, Bartolo F, Monget P, Coquery J, Yao FZ, Liquet B (2016) mixOmics: omics data integration project. $\mathrm{R}$ package version 6.1.1. https://CRAN.Rproject.org/package $=$ mixOmics. Accessed 19 April 2019

35. Carone BR, Fauquier L, Habib N, Shea JM, Hart CE, Li R, Bock C, Li C, Gu H, Zamore PD, Meissner A, Weng Z, Hofmann HA, Friedman N, Rando OJ (2010) Paternally induced transgenerational environmental reprogramming of metabolic gene expression in mammals. Cell 143(7):1084-1096. https://doi.org/10.1016/j. cell.2010.12.008

36. Do NN, Eming SA (2016) Skin fibrosis: models and mechanisms. Curr Res Transl Med 64(4):185-193. https://doi.org/10.1016/j. retram.2016.06.003

37. Uezumi A, Ito T, Morikawa D, Shimizu N, Yoneda T, Segawa M, Yamaguchi M, Ogawa R, Matev MM, Miyagoe-Suzuki Y, Takeda S, Tsujikawa K, Tsuchida K, Yamamoto H, Fukada S (2011)
Fibrosis and adipogenesis originate from a common mesenchymal progenitor in skeletal muscle. J Cell Sci 124(Pt 21):3654-3664. https://doi.org/10.1242/jcs.086629

38. Uezumi A, Fukada S, Yamamoto N, Takeda S, Tsuchida K (2010) Mesenchymal progenitors distinct from satellite cells contribute to ectopic fat cell formation in skeletal muscle. Nat Cell Biol 12(2):143-152. https://doi.org/10.1038/ncb2014

39. Li Y, Foster W, Deasy BM, Chan Y, Prisk V, Tang Y, Cummins J, Huard J (2004) Transforming growth factor-beta1 induces the differentiation of myogenic cells into fibrotic cells in injured skeletal muscle: a key event in muscle fibrogenesis. Am J Pathol 164(3):1007-1019. https://doi.org/10.1016/s0002-9440(10)63188 $-4$

40. Ismaeel A, Kim JS, Kirk JS, Smith RS, Bohannon WT, Koutakis $\mathrm{P}$ (2019) Role of transforming growth factor-beta in skeletal muscle fibrosis: a review. Int J Mol Sci. https://doi.org/10.3390/ijms2 0102446

41. Cisternas P, Henriquez JP, Brandan E, Inestrosa NC (2014) Wnt signaling in skeletal muscle dynamics: myogenesis, neuromuscular synapse and fibrosis. Mol Neurobiol 49(1):574-589. https:// doi.org/10.1007/s12035-013-8540-5

42. Ghaly A, Marsh DR (2010) Aging-associated oxidative stress modulates the acute inflammatory response in skeletal muscle after contusion injury. Exp Gerontol 45(5):381-388. https://doi. org/10.1016/j.exger.2010.03.004

43. Zhao X, Psarianos P, Ghoraie LS, Yip K, Goldstein D, Gilbert R, Witterick I, Pang H, Hussain A, Lee JH, Williams J, Bratman SV, Ailles L, Haibe-Kains B, Liu F-F (2019) Metabolic regulation of dermal fibroblasts contributes to skin extracellular matrix homeostasis and fibrosis. Nat Metab 1(1):147-157. https://doi. org/10.1038/s42255-018-0008-5

44. Zhang S, Hulver MW, McMillan RP, Cline MA, Gilbert ER (2014) The pivotal role of pyruvate dehydrogenase kinases in metabolic flexibility. Nutr Metab 11(1):10. https://doi. org/10.1186/1743-7075-11-10

45. Hunt MC, Alexson SE (2002) The role Acyl-CoA thioesterases play in mediating intracellular lipid metabolism. Prog Lipid Res 41(2):99-130. https://doi.org/10.1016/s0163-7827(01)00017-0

46. Moore GB, Himms-Hagen J, Harper ME, Clapham JC (2001) Overexpression of UCP-3 in skeletal muscle of mice results in increased expression of mitochondrial thioesterase mRNA. Biochem Biophys Res Commun 283(4):785-790. https://doi. org/10.1006/bbrc.2001.4848

47. Constantin-Teodosiu D, Constantin D, Stephens F, Laithwaite D, Greenhaff PL (2012) The role of FOXO and PPAR transcription factors in diet-mediated inhibition of PDC activation and carbohydrate oxidation during exercise in humans and the role of pharmacological activation of PDC in overriding these changes. Diabetes 61(5):1017-1024. https://doi.org/10.2337/db11-0799

48. Lundell LS, Massart J, Altintas A, Krook A, Zierath JR (2019) Regulation of glucose uptake and inflammation markers by FOXO1 and FOXO3 in skeletal muscle. Mol Metab 20:79-88. https://doi.org/10.1016/j.molmet.2018.09.011

49. Maiese $\mathrm{K}$ (2015) FoxO transcription factors and regenerative pathways in diabetes mellitus. Curr Neurovasc Res 12(4):404-413. https://doi.org/10.2174/1567202612666150807112524

50. Senoo N, Miyoshi N, Goto-Inoue N, Minami K, Yoshimura R, Morita A, Sawada N, Matsuda J, Ogawa Y, Setou M, Kamei Y, Miura S (2015) PGC-1alpha-mediated changes in phospholipid profiles of exercise-trained skeletal muscle. J Lipid Res 56(12):2286-2296. https://doi.org/10.1194/jlr.M060533 


\section{Terms and Conditions}

Springer Nature journal content, brought to you courtesy of Springer Nature Customer Service Center GmbH ("Springer Nature").

Springer Nature supports a reasonable amount of sharing of research papers by authors, subscribers and authorised users ("Users"), for smallscale personal, non-commercial use provided that all copyright, trade and service marks and other proprietary notices are maintained. By accessing, sharing, receiving or otherwise using the Springer Nature journal content you agree to these terms of use ("Terms"). For these purposes, Springer Nature considers academic use (by researchers and students) to be non-commercial.

These Terms are supplementary and will apply in addition to any applicable website terms and conditions, a relevant site licence or a personal subscription. These Terms will prevail over any conflict or ambiguity with regards to the relevant terms, a site licence or a personal subscription (to the extent of the conflict or ambiguity only). For Creative Commons-licensed articles, the terms of the Creative Commons license used will apply.

We collect and use personal data to provide access to the Springer Nature journal content. We may also use these personal data internally within ResearchGate and Springer Nature and as agreed share it, in an anonymised way, for purposes of tracking, analysis and reporting. We will not otherwise disclose your personal data outside the ResearchGate or the Springer Nature group of companies unless we have your permission as detailed in the Privacy Policy.

While Users may use the Springer Nature journal content for small scale, personal non-commercial use, it is important to note that Users may not:

1. use such content for the purpose of providing other users with access on a regular or large scale basis or as a means to circumvent access control;

2. use such content where to do so would be considered a criminal or statutory offence in any jurisdiction, or gives rise to civil liability, or is otherwise unlawful;

3. falsely or misleadingly imply or suggest endorsement, approval, sponsorship, or association unless explicitly agreed to by Springer Nature in writing;

4. use bots or other automated methods to access the content or redirect messages

5. override any security feature or exclusionary protocol; or

6. share the content in order to create substitute for Springer Nature products or services or a systematic database of Springer Nature journal content.

In line with the restriction against commercial use, Springer Nature does not permit the creation of a product or service that creates revenue, royalties, rent or income from our content or its inclusion as part of a paid for service or for other commercial gain. Springer Nature journal content cannot be used for inter-library loans and librarians may not upload Springer Nature journal content on a large scale into their, or any other, institutional repository.

These terms of use are reviewed regularly and may be amended at any time. Springer Nature is not obligated to publish any information or content on this website and may remove it or features or functionality at our sole discretion, at any time with or without notice. Springer Nature may revoke this licence to you at any time and remove access to any copies of the Springer Nature journal content which have been saved.

To the fullest extent permitted by law, Springer Nature makes no warranties, representations or guarantees to Users, either express or implied with respect to the Springer nature journal content and all parties disclaim and waive any implied warranties or warranties imposed by law, including merchantability or fitness for any particular purpose.

Please note that these rights do not automatically extend to content, data or other material published by Springer Nature that may be licensed from third parties.

If you would like to use or distribute our Springer Nature journal content to a wider audience or on a regular basis or in any other manner not expressly permitted by these Terms, please contact Springer Nature at

onlineservice@springernature.com 